\title{
KARAKTERISASI KARBON AKTIF DARI BAMBU ORI (BAMBUSA ARUNDINACEA) YANG DI AKTIVASI MENGGUNAKAN ASAM KLORIDA (HCl)
}

\author{
Saiful Huda*, Rita Dwi Ratnani dan Laeli Kurniasari \\ Jurusan Teknik Kimia, Fakultas Teknik, Universitas Wahid Hasyim \\ Jl. Menoreh Tengah X/22 Sampangan, Gajah Mungkur Kota Semarang Jawa Tengah 50232 \\ "Email : saifulhuda0302@gmail.com
}

\begin{abstract}
Abstrak
Berkembangnya industri sering memunculkan permasalahan yang berkaitan limbah yang dihasilkan. Limbah yang dihasilkan akan menimbulkan bau, warna dan rasa. Salah satu cara untuk menanggulangi masalah tersebut adalah dengan metode adsorpsi. Metode adsorpsi yang sering digunakan adalah mrnggunakan karbon aktif sebagai adsorben. Penelitian ini bertujuan untuk mengetahui karakteristik karbon aktif dari bambu Ori yang diaktivasi menggunakan asam klorida $(\mathrm{HCl})$. Karbon aktif merupakan karbon amorf yang luas permukannya sangat besar, yaitu 200 hingga $2000 \mathrm{~m} 2 / \mathrm{g}$. Bahan dasar dari karbon aktif adalah Lignoselulosa. Bambu Ori sendiri mengandung Selulosa, berkisar 42,4\% - 53,6\% dan Lignin, berkisar 19,8\% - 26,6\%. Asam klorida ( $\mathrm{HCl}$ ) yang berperan sebagai aktivator bersifat higroskopis, sehingga dapat mengurangi kadar air pada arang aktif yang dihasilkan. Pengujian dilakukan sesuai dengan SNI dan SII, meliputi uji fisik dan daya serap terhadai Iodium. Variabel suhu karbonisasi menggunakan tiga variabel suhu : 300, 400, dan $500{ }^{\circ} \mathrm{C}$, serta konsentrasi HCl: 1, 2, 3, dan 4 N. Hasil terbaik pada variabel suhu karbonisasi $300{ }^{\circ} \mathrm{C}$ dengan konsentrasi $\mathrm{HCl} 1 \mathrm{~N}$. Karakteristiknya berupa 5,9\% kadar air, 4,463 \% kadar zat mudah menguap, 9,3\% kadar abu, 80,337 \% karbon terikat, dan 698,12 mg/g daya serap terhadap Iodium. Karbon aktif dari bambu Ori ini sudah layak digunakan sebagai adsorben, karena secara garis besar sudah memenuhi standar baku mutu yang ditetapkan SII No. 025879. Baku mutu yang ditetapkan SII diantaranya, maksimal 15\% bagian yang hilang saat pemanasan, kadar air maksimal 10\%, kadar abu maksimal 2,5\%, dan daya serap terhadap $I_{2}$ minimal $200 \mathrm{mg} / \mathrm{g}$. Tetapi masih sangat dibutuhkan penelitian lebih lanjut, agar dapat memenuhi standar baku mutu SNI No. 06-3730-1995, terutama daya serap terhadap Iodium.
\end{abstract}

Kata kunci: bambu Ori, karbon aktif, aktivasi $\mathrm{HCl}$

\section{PENDAHULUAN}

Indonesia merupakan negara dengan perkembangan industri yang sangat pesat. Berkembangnya industri, sering memunculkan permasalahan yang berkaitan limbah yang dihasilkan.Salah satu cara untuk menanggulangi masalah berkaitan dengan limbah suatu adalah dengan metode adsorpsi.Metode adsorpsi adalah metode yang paling efektif, dimana prinsip metode ini ialah bahan tertentu di serap oleh suatu bahan yang bersifat sebagai penyerap (Hutapea dkk., 2017).

Salah satu jenis adsorben yang paling potensial dalam proses adsorpsi adalah karbon aktif. Karbon aktif merupakan suatu padatan berpori yang mengandung 85-95 \% karbon, dihasilkan dari bahan-bahan yang mengandung karbon dengan pemanasan pada suhu tinggi (Nafi'ah, 2016).

Karbon aktif merupakan karbon amorf yang luas permukannya sangat besar, yaitu 200 hingga $2000 \mathrm{~m}^{2} / \mathrm{g}$ (Miranti, 2012). Karbon aktif sering kali digunakan sebagai adsorben saat proses adsorpsi, dikarenakan karbon aktif memiliki daya adsorp lebih baik dibandingkan adsorben lainnya.

Pengembangan bahan baku pembuatan karbon aktif sudah banyak dilakukan, diantaranya menggunakan batubara dan bahanbahan organik dengan kandungan karbon yang tinggi. Diantaranya, dari tempurung kelapa, serat kayu, dan dari bambu (Miranti, 2012). Salah satu material yang dapat digunakan dalam proses pembuatan arang aktif adalah tanaman bambu.

Bambu merupakan tanamaan berbentuk bulat yang hidupnya merumpun, memiliki banyak ruas dan merupakan sejenis tanaman rumput-rumputan. Bambu adalah Selulosa berkisar 42,4\% - 53,6\% dan Lignin berkisar 19,8\% - 26,6\%(Hutapea dkk., 2017). Salah satu jenis bambu yang mudah di dapat adalah bambu Ori. Bambu Ori memiliki batang yang tebal dan rongga di dalam batang kecil, dibandingkan bambu Apus yang memiliki rongga besar dan batang tipis. Dengan menggunakan bahan baku dari bambu Ori ini, diharapkan karbon aktif yang di hasilkan lebih banyak. 
Asam klorida merupakan senyawa yang dapat mengklorinasi bahan-bahan hidrokarbon. Asam klorida $(\mathrm{HCl})$ ini terurai dalam air dan mengeluarkan panas pada proses pelarutannya. Asam klorida larut didalam air pada tekanan atmosfer dan suhu kamar yaitu sebesar $42 \%$ berat (Wirani, 2017).Asam klorida $(\mathrm{HCl})$ yang berperan sebagai aktivator bersifat higroskopis, sehingga dapat mengurangi kadar air pada arang aktif yang dihasilkan. $\mathrm{HCl}$ memiliki daya jerap ion lebih baik dibandingkan dengan aktivator lainnya, seperti $\mathrm{H} 2 \mathrm{SO} 4$ dan $\mathrm{HNO} 3$, dikarenkan $\mathrm{HCl}$ dapat melarutkan pengotor lebih besar, sehingga pori-pori yang terbentuk lebih banyak dan proses penjerapan menjadi lebih maksimal (Wirani, 2017).

\section{METODOLOGI}

\section{Bahan Dan Alat}

Bahan yang digunakan pada penelitian ini di antaranya adalah bambu Ori, $\mathrm{HCl}$ pekat, aquadest, kertas saring halus, larutan Natrium Tiosulfat (Na2S2O3) 0,1 N, larutan Iodine 0,1 $\mathrm{N}$, indikator Amylum $1 \%$, alumunium foil.

Sedangkan alat yang digunakan meliputi, Pirolisator, Furnace, Oven, penangas listrik, Neraca analitik, Ayakan dengan ukuran 100 mesh, Cawan porselin, Desikator, Ember, Erlenmayer, Gelas ukur, Labu ukur, Buret, dan Magnetic stirrer.

\section{Preparasi Bahan Baku}

Langkah awal pembuatan karbon aktif dimulai dari bersihkan bambu, potong kecilkecil, kurang lebih berukuran 3-6 cm dan keringkan di bawah terik matahari.

\section{Proses Karbonisasi}

Karbonisasi dalam pirolisator dengan variasi suhu 300,400 , dan $500^{\circ} \mathrm{C}$ selama 1 jam. Pada saat proses karbonisasi,indikator suhu menggunakan thermometer tembak. Dengan cara arahkan sensor infrared ke arah pirolisator bagian bawah. Dinginkan dalam desikator, kemudian timbang sebayak 30 gram untuk proses aktivasi.

\section{Aktivasi Karbon Aktif}

Arang yang sudah di timbang diaktivasi secara kimia, dengan di rendam menggunakan aktivator asam, yaitu $\mathrm{HCl}$. Konsentrasi yang telah ditentukan adalah $1 \mathrm{~N}, 2 \mathrm{~N}, 3 \mathrm{~N}$, dan $4 \mathrm{~N}$ selama 24 jam, kemudian tiriskan.

Karbon aktif yang sudah teraktivasi selanjutnya dicuci dengan aquadest sampai $\mathrm{pH}$ netral. Keringkan menggunakan oven, pada suhu $110^{\circ} \mathrm{C}$ selama $1 \mathrm{jam}$, dan dinginkan.Proses selanjutnya yaitu crusher karbon aktif dan diayak menggunakan ukuran mesh 100.

\section{ANALISA KWALITAS KARBON AKTIF}

Adapun pengujian kwalitas karbon aktif meliputi, analisa kadar air, analisa kadar zat yang menguap, analisa kadar abu, anlisa kadar karbon tetap, dan analisa daya serap terhadap Iodium.

\section{Analisa Kadar Air}

Karbon aktif sebanyak 1 g dikeringkan dalam oven selama 3 jam hingga bobot konstan dengan suhu $105^{\circ} \mathrm{C}$ sampai beratnya konstan. Kemudian dimasukkan ke dalam desikator sampai bobotnya tetap. Setiap 1 jam pengeringan, timbang sampel hingga bobot konstan (Rizky, 2015).

\section{Analisa Kadar Zat Menguap}

Sebanyak 1 gram karbon aktif dimasukkan kedalam cawan porselen berpenutup, dan masukkan kedalam furnace pada suhu $950^{\circ} \mathrm{C}$ selama 6 menit. Setelah penguapan selesai, cawan dimasukkan ke dalam desikator sampai beratnya konstan, kemudian timbang (Lestari dkk., 2017).

\section{Analisa Kadar Abu}

Cawan yang berisi sampel karbon aktif tiap variabel diletakkan dalam tanur, panaskan hingga suhu $600^{\circ} \mathrm{C}$ selama 6 jam. Selanjutnya didinginkan dalam desikator sampai beratnya konstan, kemudian timbang beratnya (Lestari dkk., 2017).

\section{Analisa Karbon Tetap}

Karbon aktif murni dilakukan dengan mengitung selisih antara seratus persen dengan nilai hasil penjumlahan kadar abu dan zat yang menguap (Lestari dkk, 2017).

\section{Analisa Daya Serap Iodium}

Timbang karbon aktif yang sudah kering sebanyak 0,5 g dan masukkan ke dalam erlenmeyer. Kemudian tambahkan $25 \mathrm{ml}$ larutan iodin $0,1 \mathrm{~N}$ dan kocok selama 15 menit. Campuran disaring dan ambil filtrat sebanyak $10 \mathrm{ml}$. Selanjutnya filtrat dititrasi dengan larutan Natrium Tiosulfat (Na2S2O3) 0,1 N hingga warna menjadi kuning muda. Lalu tambahkan beberapa tetes indikator amilum 1\% 
dan titrasi kembali hingga warna biru tepat hilang (Suhendrawati dkk, 2013).

$$
\text { DSI }=\frac{\left(\text { ml sampel }-\frac{\mathrm{T} \times \mathrm{C} 1}{\mathrm{C} 2}\right) \times \text { WI } \times \mathrm{Fp}}{\text { berat sampel karbon aktif }}
$$

Dimana:

DSI = Daya serap Iodin $(\mathrm{mg} / \mathrm{g})$

$\mathrm{ml}$ sampel = Sampel filtrat yang dititrasi $(\mathrm{ml})$

$\mathrm{T}=$ Volume tirasi $\mathrm{Na}_{2} \mathrm{~S}_{2} \mathrm{O}_{3}(\mathrm{ml})$

$\mathrm{C}_{1} \quad=$ Konsentrasi $\mathrm{Na}_{2} \mathrm{~S}_{2} \mathrm{O}_{3}(\mathrm{~N})$

$\mathrm{C}_{2} \quad=$ Konsentrasi $\operatorname{Iodin}(\mathrm{N})$

WI $=$ Berat Iodin $(12,693 \mathrm{mg} / \mathrm{ml})$

$\mathrm{Fp} \quad=$ Faktor pengencer (5)

\section{HASIL DAN PEMBAHASAN}

Tabel 1. Standar Kwalitas Karbon Aktif (SNI 1995 dan SII No. 2058-79)

\begin{tabular}{lll}
\hline \multirow{2}{*}{ Uraian } & \multicolumn{2}{l}{ Persyaratan Kualitas } \\
\cline { 2 - 3 } & SNI & SII \\
\hline $\begin{array}{l}\text { Bagian yang hilang pada } \\
\text { pemanasan 950 C, (\%) }\end{array}$ & Maks.25 & Maks. 15 \\
$\begin{array}{l}\text { Kadar air, (\%) } \\
\text { Kadar abu, (\%) }\end{array}$ & Maks. 15 & Maks. 10 \\
$\begin{array}{l}\text { Kadar Karbon Terikat } \\
(\%)\end{array}$ & Min 65 10 & Maks. 2,5 \\
$\begin{array}{l}\text { Daya serap terhadap } \mathrm{I}_{2}, \\
(\mathrm{mg} / \mathrm{g})\end{array}$ & Min. 750 & Min. 200 \\
\hline
\end{tabular}

\section{Hasil Analisa Kadar Air}

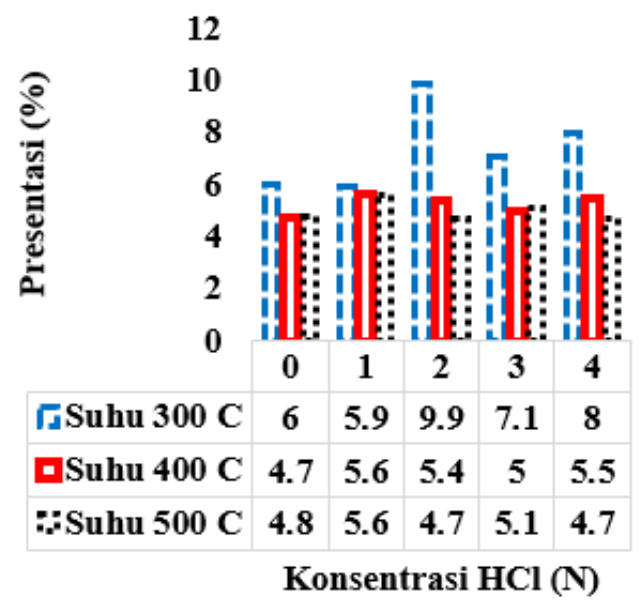

\section{Gambar 1. Pengaruh Konsentrasi HCl Terhadap Analisa Kadar Air}

Kadar air mengalami penurunan seiring bertambahnya suhu karbonisasi yang digunakan. H2O mengalami perubahan fase, dari cair menjadi gas setelah mencapai titik didihnya, yaitu pada suhu $100{ }^{\circ} \mathrm{C}$ (Purbacaraka dkk., 2017). Dalam proses karbonisasi, semakin tinggi suhu karbonisasi maka semakin meningkat pula air yang menguap, sehingga kadar airnya semakin rendah (Fauziah, 2011). Berdasarkan Gambar 1. diatas dapat disimpulkan, bahwa kadar air sudah sesuai teori dan memenuhi standar baku mutu yang telah ditetapkan SII No. 0258-79 dan SNI 06-37301995 yaitu maksimal sebesar $10 \%$ dan $15 \%$.

\section{Hasil Analisa Kadar Zat Menguap 14.000

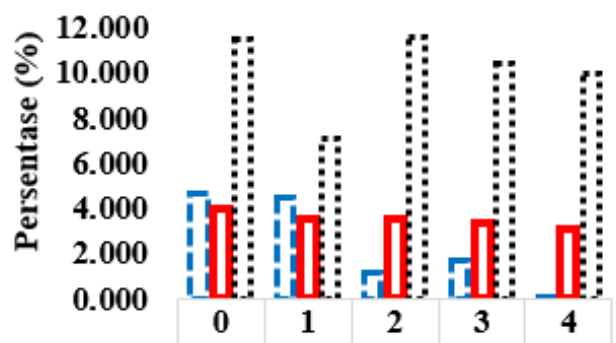 \\ 「]300 C 4.6814 .4631 .1101 .7220 .109 \\ 口400 C 3.9873 .4963 .4883 .3683 .069 \\ $\because 500 \mathrm{C} 11.457 .09711 .5410 .439 .969$}

\section{Konsentrasi $\mathrm{HCl}(\mathrm{N})$}

Gambar 2. Pengaruh Konsentrasi HCl Terhadap Analisa Kadar Zat Menguap

Pada penelitian ini kadar zat menguap terendah yaitu pada variabel suhu karbonisasi $300{ }^{\circ} \mathrm{C}$ dan konsentrasi $\mathrm{HCl} 4 \mathrm{~N}$, sebesar $0,109 \%$ dan kadar zat menguap tertinggi yaitu pada variabel suhu $500{ }^{\circ} \mathrm{C}$ dengan konsentrasi $\mathrm{HCl} 2 \mathrm{~N}$, yaitu sebesar 11,542 \% . Meningkatnya suhu karbonisasi cenderung menurunkan kadar zat menguap. Hal ini terjadi karena pada suhu tinggi proses penguraian senyawa nonkarbon berlangsung secara sempurna (Purbacaraka dkk., 2017). Gambar 2. Menunjukkanpengaruh suhu karbonisasi terhadap kadar zat menguap karbon aktif yang semakin tinggi seiring meningkatnya suhu karbonisasi.

Semakin tinggi kadar zat menguap maka kemampuan karbon aktif untuk mengadsorpsi semakin menurun. Meskipun hasil penelitian tidak sesuai teori, tetapi hasil pengujian kadar zat menguap pada penelitian ini yang telah memenuhi standar baku mutu karbon aktif berdasarkan SNI 06-3730-1995 dengan parameter maksimal $25 \%$ dan SII No. 2058-79 dengan syarat maksimal $15 \%$. 


\section{Hasil Analisa Kadar Abu \\ 14.000

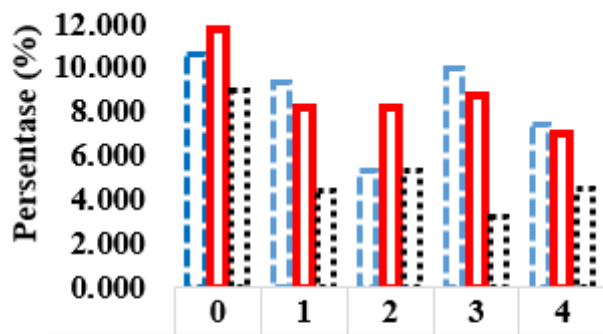 \\ 「 $300 \mathrm{C} 10.609 .3005 .30010 .007 .400$ \\ 口400 C 11.808 .2008 .2008 .7007 .000 \\ :500 C 9.0004 .4005 .3003 .2004 .500 \\ Konsentrasi $\mathrm{HCl}(\mathrm{N})$}

\section{Gambar 3. Pengaruh Konsentrasi HCl Terhadap Analisa Kadar Abu}

Hasil penelitian ini kadar abu yang diperoleh berkisar antara 3,2 \% - 11,8\% seperti pada Gambar 3. Hasil pengujian kadar abu tidak sesuai teori. Semakin tinggi suhu karbonisasi, maka kadar abu yang dihasilkan akan semakin meningkat. Kadar abu tinggi disebabkan oleh kandungan unsur anorganik teroksidasi membentuk senyawa abu pada suhu tinggi, sehingga menyebabkan endapan unsur anorganik menempel pada permukaan karbon aktif (Purbacaraka dkk., 2017).

Pada penelitian kali ini, kadar abu yang diperoleh tidak memenuhi standar baku mutu SII No. 0258-79 dengan parameter maksimal 2,5\%, tetapi kadar abu pada karbon aktif yang teraktivasi menggunakan $\mathrm{HCl}$ memenuhi standar baku mutu SNI 1995 dengan parameter $10 \%$.

\section{Hasil Analisa Karbon Terikat}

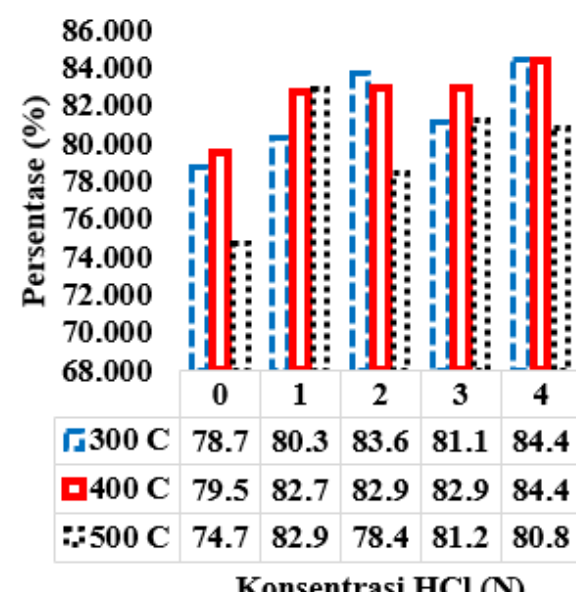

Gambar 4. Pengaruh Konsentrasi HCl Terhadap Karbon Terikat
Karbon terikat dipengaruhi oleh kadar abu dan kadar zat menguap pada arang aktif yang dihasilkan. Kadar karbon terikat merupakan pengurangan jumlah kadar abu dan kadar zat menguap. Semakin meningkat suhu karbonisasi, maka karbon terikat pada karbon aktif akan menurun (Purbacaraka dkk., 2017). Pada penelitian kali ini hasil karbon terikat berkisar antara $74,75 \%-84,491 \%$ dan yang sesuai teori adalah adalah pada konsentrasi $\mathrm{HCl}$ 2 dan $4 \mathrm{~N}$ yang terlihat pada Gambar 4 . Tetapi secara keseluruhan sudah memenuhi standar baku mutu SNI No. 06-3730-1995 yaitu minimal sebesar $65 \%$.

\section{Hasil Analisa Daya Serap Iodium $\mathbf{8 0 0 . 0 0}$

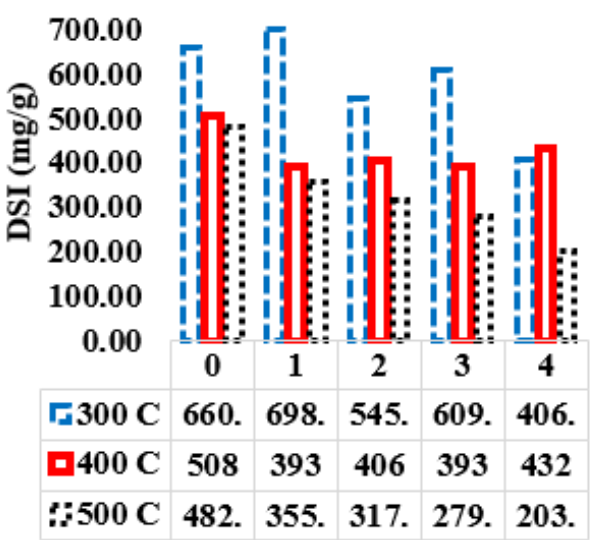

Konsentrasi $\mathrm{HCl}(\mathrm{N})$

Gambar 5. Pengaruh Konsentrasi HCl Terhadap Daya Serap Larutan Iodium

Gambar 5. Menunjukkanbahwa daya serap terhadap larutan Iodium semakin menurun seiring bertambahnya suhu karbonisasi. Pada penelitian kali ini daya serap terhadap Iodium karbon aktif yang diperoleh berkisar antara $203,09 \mathrm{mg} / \mathrm{g}-698,12 \mathrm{mg} / \mathrm{g}$. Nilai daya serap Iodium tertinggi terdapat pada suhu karbonisasi $300{ }^{\circ} \mathrm{C}$ dengan konsentrasi $\mathrm{HCl} 1 \mathrm{~N}$.

Hasil penelitian daya serap Iodium tidak sesuai teori, semakin tinggi suhu karbonisasi, daya serap Iodium semakin menurun, yang terlihat pada Gambar 5. Hal ini dikarenakansemakin tinggi suhu karbonisasi, maka luas permukaan dan jumlah pori-pori karbon aktif yang terbentuk semakin luas, dan pori-pori pada karbon aktif semakin besar, sehingga kemampuan karbon aktif untuk mengadsopsi semakin meningkat (Purbacaraka dkk., 2017). Akan tetapi daya serap Iodium karbon aktif yang dihasilkan sesuai standar 
baku mutu SII No. 0258-79 yaitu minimal sebasar $200 \mathrm{mg} / \mathrm{gr}$.

\section{KESIMPULAN}

Berdasarkan dari data hasil penelitian yang telah di analisis dan dibahas, dapat di ambil kesimpulan sebagai berikut :

a. Karbon aktif dapat di buat dari bambu Ori, hal ini dibuktikan bahwa kadar karbon yang diperoleh berkisar antara 74,75 \% - 84,491 $\%$. Hal ini sesuai dengan standar baku mutu SNI No. 06-3730-1995 yaitu minimal sebesar $65 \%$.

b. Karakteristik karbon aktif dari bambu Ori yang diaktivasi menggunakan $\mathrm{HCl}$, hasil terbaik pada variabel suhu karbonisasi 300 ${ }^{\circ} \mathrm{C}$ dengan konsentrasi $\mathrm{HCl} 1 \mathrm{~N}$. Karakteristiknya berupa 5,9\% kadar air, 4,463\% kadar zat mudah menguap, 9,3\% kadar abu, 80,337 \% karbon terikat, dan $698,12 \mathrm{mg} / \mathrm{g}$ daya serap terhadap Iodium.

c. Kadar air, kadar zat menguap sudah memenuhi standar SNI, akan tetapi untuk kadar abu dan daya serap terhadap Iodium belum memenuhi standar SNI.

\section{SARAN}

1. Perlu dilakukan penelitian lebih lanjut untuk mengetahui pemanfaatan arang aktif dari bambu Ori selain sebagai adsorben.

2. Pada penimbangan tiap sampel gunakanlah timbangan yang valid dan terkalibrasi, agar menghasilkan karbon aktif sesuai dengan yang diharapkan dan tidak menyimpang dari ketentuan.

3. Daya serap terhadap Iodium dari hasil penelitian tidak sesuai dengan standar SNI. Penelitian selanjutnya dapat ditingkatkan lagi daya serapnya, salah satunya dengan cara menambah waktu aktivasi.

\section{DAFTAR PUSTAKA}

Asrijal., Chadijah, S., Aisyah., 2013, Variasi Konsentrasi Aktivator Asam Sulfat Pada Karbon Aktif Ampas Tebu Terhadap Kapasitas Adsorpsi Logam Timbal, Hal 33-44, Jurusan Kimia, Fakultas Sains dan Teknologi, UIN Alauddin Makassar.

Hutapea, E., M., Iwantono, I., Farma, R., Saktiono, S., Awitdrus, A., 2017, Pembuatan Dan Karakterisasi Karbon Aktif Dari Bambu Betung (Dendrocalamus Asper) Dengan Aktivasi KOH Berbantuan Gelombang Mikro, Program Studi S1 Fisika, FMIPA, Universitas Riau.
Imawati, A., Adhitiyawan, 2015, Kapasitas Adsorpsi Maksimum Ion $\mathrm{Pb}$ (II) Oleh Arang Aktif Ampas Kopi Teraktivasi $\mathrm{HCl}$ Dan $\mathrm{H}_{3} \mathrm{PO}_{4}$, Program Studi Kimia, Fakultas MIPA, Universitas Tanjungpura.

Junaidi, L., Wijaya, H., 2011, Efektivitas Arang Bambu Sebagai Filter Asap Rokok, Jurnal of Agro Based Industry, Vol. 28, No. 1, Balai Besar Industri Agro Bogor.

Khuluk, R., H., 2016, Pembuatan Dan Karakterisasi Karbon Aktif Dari Tempurung Kelapa (Cocous Nucifera L.) Sebagai Adsorben Zat Warna Metilen Biru, Jurusan Kimia, Fakultas MIPA, Universitas Lampung Bandarlampung.

Lestari, K., D., Ratnani, R., D., Suwardiyono, S., 2017, Pengaruh Waktu Dan Suhu Pembuatan Karbon Aktif Dari Tempurung Kelapa Sebagai Upaya Pemanfaatan Limbah Dengan Suhu Tinggi Secara Pirolisis, Jurusan Teknik Kimia, Fakultas Teknik, Universitas Wahid Hasyim Semarang.

Masdar, A., Zulfrimar., Novianti., Putri, D., 2013, Penggunaan Ranting Bambu Ori Sebagai Konektor Pada Struktur Truss Bambu. Konverensi Nasional Teknik Sipil 7. Hal 85-89. Universitas Sebelas Maret Surakarta.

Miranti, S., T., Sudibandriyo, M., 2012, Pembuatan Karbon Aktif Dari Bambu Dengan Metode Aktivasi Terkontrol Menggunakan Activating Agent $\mathrm{H}_{3} \mathrm{PO}_{4}$ Dan KOH, Laporan Penelitian, Jurusan Teknik Kimia, Fakultas Teknik, Universitas Indonesia.

Nafi'ah, R., 2016, Kinetika Adsorpsi Pb (II) Dengan Adsorben Arang Aktif Dari Sabut Siwalan, Jurnal Farmasi Sains Dan Praktis, Vol. I, No. 2, Sekolah Tinggi Ilmu Farmasi Semarang.

Polii, F., F., 2017, Pengaruh Suhu Dan Lama Aktifasi Terhadap Mutu Arang Aktif Dari Kayu Kelapa, Balai Riset Dan Standarisasi Industri Manado.

Purbacaraka, F., H., Ratnani, R., D., Hartati, I., 2017, Uji Karakteristik Karbon Aktif Dari Limbah Arang Boiler Dengan Variabel Jenis Kayu Dan Suhu Karbonisasi, Laporan Penelitian, Program Studi Teknik Kimia, Fakultas Teknik, Universitas Wahid Hasyim Semarang.Rahmadani, N., Kurniawati, P., 2017, Sintesis Dan Karakterisasi Karbon Teraktivasi Asam Dan Basa Berbasis Mahkota Nanas, D III 
Analisis Kimia, FMIPA, Universitas Islam Indonesia.

Rasdiansyah, R., Darmadi, D., Supardan, M., D., 2014, Optimasi Proses Pembuatan Karbon Aktif Dari Ampas Bubuk Kopi Menggunakan Aktivator $\mathrm{ZnCl}_{2}$, Jurnal Teknologi Dan Industri Pertanian Indonesia, Vol. 06, No. 03, Jurusan Teknologi Hasil Pertanian, Universitas Syiah Kuala.

Rizky, I., P., Susatyo, E., B., Sulistyaningsih, E., 2015, Aktivasi Arang Tongkol Jagung Menggunakan $\mathrm{HCl}$ Sebagai Adsorben Ion Cd (II), Laporan Penelitian, Jurusan Kimia, Fakultas Matematika Dan Ilmu Pengetahuan Alam, Universitas Negeri Semarang.

Suhendrawati, L., Suharto, B., Susanawati, L., D., 2013, Pengaruh Konsentrasi Larutan Kalium Hidroksida Pada Abu Dasar Ampas Tebu Teraktivasi, Fakultas Teknologi Pertanian, Universitas Brawijaya Malang.

Widayatno, T., Yuliawati, T., Susilo, A., A., 2017, Adsorpsi Logam Berat (Pb) Dari Limbah Cair Dengan Adsorben Arang Bambu Aktif, Jurnal Teknologi Bahan Alam, Vol. 1, No. 1, Program Studi Teknik Kimia, Fakultas Teknik, Universitas Muhammadiyah Surakarta.

Wirani, I., L., Hanum, F., Dina, S., F., 2017, Aktivasi Karbon Dari Sekam Padi Dengan Aktivator Asam Klorida ( $\mathrm{HCl})$ Dan Pengaplikasiannya Pada Limbah Pengolahan Baterai Mobil Untuk Mengurangi Kadar Timbal ( $\mathrm{Pb})$, Laporan Penelitian, Jurusan Teknik Kimia, Fakultas Teknik, Universitas Sematera Utara.

Yulianti, A., Taslimah, T., Sriatun, S., 2010, Pembuatan Arang Aktif Tempurung Kelapa Sawit Untuk Pemucatan Minyak Goreng Sekali Pakai, Jurnal Kimia Sains Dan Aplikasi 13 (2), Jurusan Kimia, Fakultas MIPA, Universitas Diponegoro Semarang. 